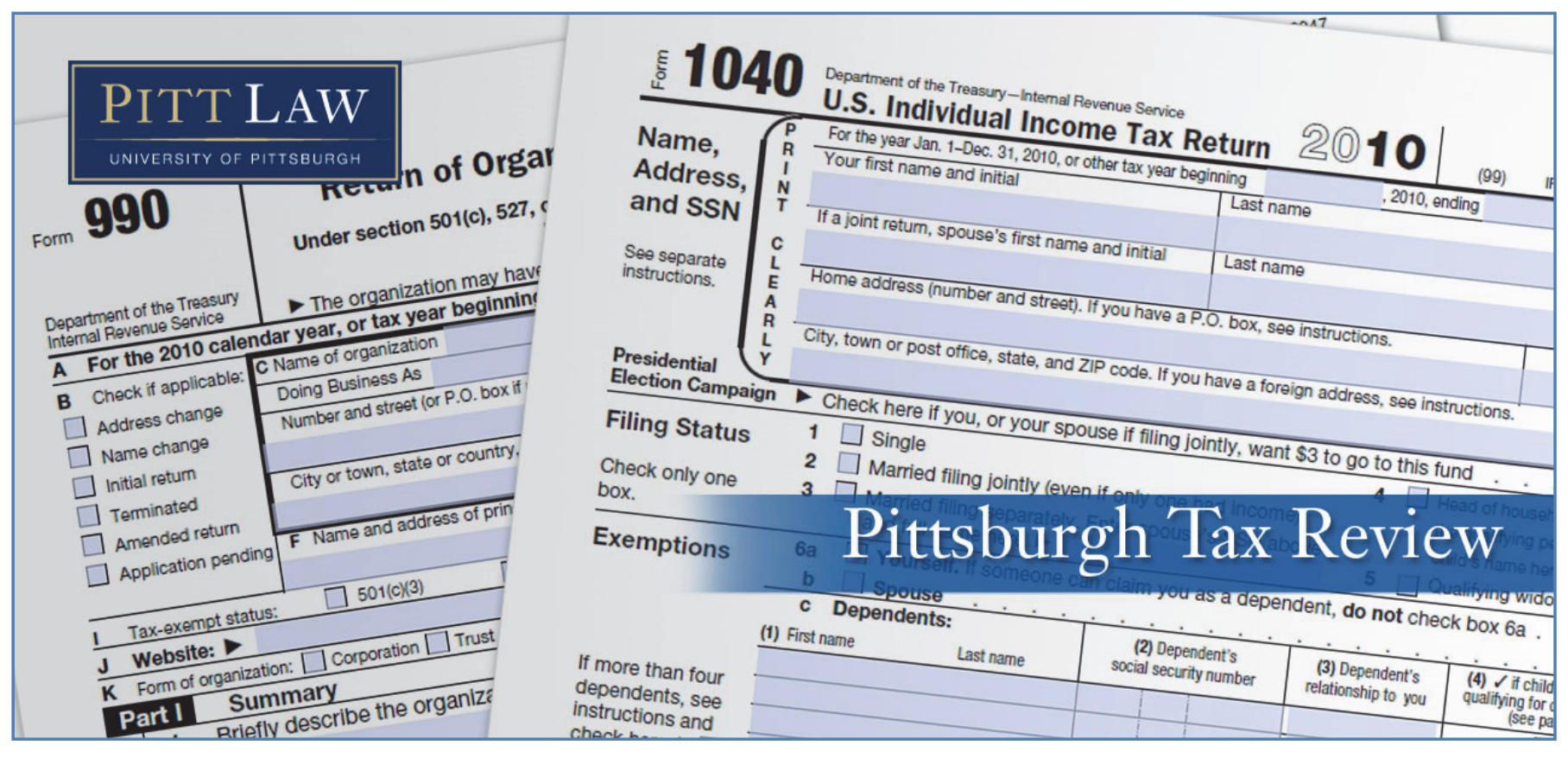

Volume 12 (2015) | ISSN 1932-1821 (print) 1932-1996 (online)

DOI 10.5195/taxreview.2015.34 | http://taxreview.law.pitt.edu

\title{
ESSAY
}

\section{MY LAST TIME}

William J. Brown

Emeritus Professor, University of Pittsburgh School of Law

\section{$(\mathrm{Cc}) \mathrm{BY}-\mathrm{NC}-\mathrm{ND}$}

This work is licensed under a Creative Commons Attribution-Noncommercial-No Derivative Works 3.0 United States License.

\section{ULLS DD-Soref}

This journal is published by the University Library System of the University of Pittsburgh as part of its D-Scribe Digital Publishing Program, and is cosponsored by the University of Pittsburgh Press. 


\section{ESSAY}

\section{MY LAST TIME}

\section{William J. Brown \\ Emeritus Professor, University of Pittsburgh School of Law}

At a time when apparently inexorable increases in wealth disparity are drawing attention, ${ }^{*}$ it seems appropriate to consider eliminating at least one basic way in

${ }^{*}$ See, e.g., Remarks by President Barack Obama at THEARC, December 4, 2013 :

The top 10 percent no longer takes in one-third of our income-it now takes half. Whereas in the past, the average CEO made about 20 to 30 times the income of the average worker, today's CEO now makes 273 times more. And meanwhile, a family in the top 1 percent has a net worth 288 times higher than the typical family, which is a record for this country.

Full Transcript: President Obama's December 4 Remarks on the Economy, WASH. PosT (Dec. 4, 2013), http:// www.washingtonpost.com/politics/running-transcript-president-obamas-december-4-remarks-onthe-economy/2013/12/04/7cec31ba-5cff-11e3-be07-006c776266ed_story.html. The President characterized this "dangerous and growing inequality and lack of upward mobility that has jeopardized middle-class America's basic bargain - that if you work hard, you have a chance to get ahead," as "the defining challenge of our time." Id.

Among the values rooted in our nation's history, Federal Reserve Chair Janet L. Yellen observed at a Conference on Economic Opportunity and Inequality on October 17, 2014, is "the high value Americans have traditionally placed on equality of opportunity." Janet L. Yellen, Federal Reserve Chair, Remarks at the Conference on Economic Opportunity and Inequality, Federal Reserve Bank of Boston: Perspectives on Inequality and Opportunity from the Survey of Consumer Finances (Oct. 17, 2014). Even more foreboding than President Obama's comments on this topic, she stated, "[t]he extent of and continuing increase in inequality in the United States greatly concerns me." Id. As Yellen points out, "The distribution of wealth is even more unequal than that of income." Id. Drawing from the Federal Reserve's triennial Survey of Consumer Finances,

[s] hows that wealth inequality has increased more than income inequality since 1989 . The wealthiest 5 percent of American households held 54 percent of all wealth reported in the 1989 survey. Their share rose to 61 percent in 2010 and reached 63 percent in 2013. By contrast, the rest of those in the top half of the wealth distribution - families that in 2013 had a net worth between $\$ 81,000$ and $\$ 1.9$ million-held 43 percent of wealth in 1989 and only 36 percent in 2013.

Id.

Pitt Tax Review | ISSN 1932-1821 (print) 1932-1996 (online)

DOI 10.5195/taxreview.2015.34 | http://taxreview.law.pitt.edu 
which the Internal Revenue Code contributes to that trend. This essay will propose limiting the availability of relatively lenient long-term capital gain tax rates to profits realized only by the original issuees of corporate stock.

I.

Because money begets money, anyone with accumulated capital is naturally in a position to outpace those who lack capital to invest. Short of confiscating excessive hordes of accumulated capital, ${ }^{1}$ one of the few ways

Income generated by accumulated wealth tends to widen the gap, especially when assisted by a fifteen percent (or twenty percent) rate of federal income taxation on dividends. While ripe for attention and correction, that is beyond the scope of this paper's topic of capital gains taxation (as discussed during my last time testifying before the U.S. House Ways and Means Committee). To be sure, the gracing of realized capital gains with a tax rate roughly half (or less) that applicable to ordinary income serves to boost wealth inequality.

While President Obama's remarks at THEARC, quoted above, include a conjunctive link between "growing inequality and lack of upward mobility," that seemingly natural association may not be inevitable. A recent Harvard University study led by Raj Chetty, with Nathaniel Hendren, Patrick Kline, Emmanuel Saez and Nicholas Turner, indicates that climbing the economic ladder is no more difficult today than ever. Raj Chetty et al., Is the United States Still a Land of Opportunity? Recent Trends in Intergenerational Mobility, NAT'L BUREAU ECON. RES. (Jan. 2014), http://www.nber.org/ papers/w19844.pdf. Massachusetts Institute of Technology economist David Autor suggests that this indicates "social policies have fought market forces to a draw." Jim Tankersley, Study: Economic Mobility Hasn't Changed over Decades, ST. LouIs Post-DisPatch (Jan. 23, 2014), http://www.stltoday .com/business/local/study-economic-mobility-hasn-t-changed-over-decades/article $73 \mathrm{cf} 217 \mathrm{~d}-8 \mathrm{c} 15$ -

5249-9680-13453f0027a4.html. As Harvard economist and mobility scholar Lawrence Katz observes, "because there is so much inequality, people born near the bottom tend to stay near the bottom, and that's much more consequential than it was 50 years ago." Jim Tankersley, Economic Mobility Hasn't Changed in a Half-century in America, Economists Declare, WASH. POST (Jan. 23, 2014), http://www .washingtonpost.com/business/economy/economic-mobility-hasnt-changed-in-a-half-century-in-america -economists-declare/2014/01/22/e845db4a-83a2-11e3-8099-9181471f7aaf story.html; see also THOMAS PIKETTY, CAPITAL IN THE TWENTY-FIRST CENTURY (Arthur Goldhammer trans., 2013); Eduardo Porter, Q\&A: Thomas Picketty on the Wealth Divide, N.Y. TIMES ECONOMIX BLOG (Mar. 11, 2014, 6:21 PM), http://economix.blogs.nytimes.com/2014/03/11/qa-thomas-piketty-on-the-wealth-divide/?_r=0.

${ }^{1}$ Senator George McGovern, Democratic Party candidate for President of the United States in 1972 , suggested that individuals be required to pay at death a $77 \%$ tax on the cumulative value of property transferred in excess of $\$ 500,000$. George McGovern \& Wassily Leontief, George McGovern: On Taxing \& Redistributing Income, 18 NEW YORK REVIEW OF BOOKS 7 (1972); see also William Voegeli, Why Populism Isn't Popular, L.A. TIMES (Nov. 29, 2010), http:/articles.latimes.com/2010/ nov/29/opinion/la-oe-voegeli-populism-20101129. Though McGovern's election campaign hardly made this into a referendum issue, it is notable that he only carried one state (Massachusetts) and the District of Columbia in the general election. Gerhard Peters \& John T. Woolley, Election of 1972, AMER. PRESIDENCY PROJECT, http://www.presidency.ucsb.edu/showelection.php?year=1972 (last visited Apr. 2, 2015)

Federal gift, estate, and generation-skipping transfer taxes long served as reasonable checks on large-scale accumulations of wealth whenever the owner engaged in gratuitous transfers (other than to

Pitt Tax Review | ISSN 1932-1821 (print) 1932-1996 (online)

DOI 10.5195/taxreview.2015.34 | http://taxreview.law.pitt.edu 
of meaningfully addressing our growing wealth and income gap is through the federal income tax. ${ }^{2}$ The relatively low rates at which certain returns on

charity). See Boris I. BitTKer \& LAWRENCE LOKKen, Federal TAXATION OF INCOME, Estates \& GIFT $\uparrow 120.1$ (2015), available at 1997 WL 440113. Under President Obama, those imposts were substantially undercut — and relegated to playing a fairly peripheral role in the attempt to limit outsized accumulations of wealth - by generous exemption allowances of $\$ 5$ million for single individuals and $\$ 10$ million for married couples (facilitated by "portability" of the first-deceased spouse's exemption) and a top rate of $40 \%$. I.R.C. $\S \S 2001,2010$. The exemption allowances benefit from being adjusted for inflation, in consequence of which the original $\$ 10$ million has already climbed above $\$ 10.8$ million. In turn, estate planners significantly magnify the exemption amounts by assorted means (Qualified Personal Residence Trusts, Grantor-Retained Annuity Trusts or Uni-Trusts, and Family Limited Partnerships, for example) fairly assured of success by legislative allowance, Revenue Code regulation, or judicial precedent. See Robert E. Ward, Planning Opportunities in the American Taxpayer Relief Act of 2012, PRACTICAL TAX LAW. 47, 47 (2013), available at http://www.rewardlaw.com/uploads/1/0/6/2/ 10627797/planning_opportunities.pdf.

When best-selling author-economist Thomas Picketty was asked what should be done to counteract the current accumulation of wealth into very few hands, he responded: "The ideal solution is a progressive tax on individual net wealth [to] foster wealth mobility and keep concentration under control and under public scrutiny." Porter, supra note *. In a separate article Eduardo Porter notes, "[p]rogressive wealth taxes could reduce the after-tax return to capital so that it equaled the rate of economic growth." Eduardo Porter, A Relentless Widening of Disparity in Wealth, N.Y. TIMES, Mar. 11, 2014, at B1. Given recent changes reducing the impact of what opponents pejoratively called "the death tax," however, its resurgence seems unlikely: "The holders of wealth, hardly a powerless bunch, will oppose any such move, even if that's what is needed to preserve capitalism against the populist impulses of those left behind," Porter predicts. Id.

The challenge posed by our widening national wealth/income gap is compounded by Citizens United. See Citizens United v. Fed. Election Comm'n, 558 U.S. 310 (2010) (holding that corporate political spending constitutes an exercise of free speech protected by the First Amendment). As Joseph E. Stiglitz, Nobel laureate in economics and moderator of a recent series, The Great Divide, in The New York Times points out, "The American political system is overrun by money. Economic inequality translates into political inequality, and political inequality yields increasing economic inequality." Inequality Is Not Inevitable, N.Y. TIMES OPINIONATOR BlOG (June 27, 2014, 6:16 PM), http:// opinionator.blogs.nytimes.com/2014/06/27/inequality-is-not-inevitable/?_r=0. Despite this ominous cycle, Stiglitz observes, "[w]idening and deepening inequality is not driven by immutable economic laws, but by laws we have written ourselves." Id. That's heartening, as "laws we have written ourselves" can be revised, though the odds may be against it. Apologists for the most wealthy could still succeed in espousing theories earlier disproved by experience (such as, "lower tax rates will raise more revenue," "tax cuts for corporations and wealthy people promote growth," or "wealth trickles down"). There's a danger, Princeton economics professor Paul Krugman points out, in "the enduring power of bad ideas," when "those ideas serve the interests of the right people." Paul Krugman, Charlatans, Kranks and Kansas, N.Y. TIMES, June 30, 2014, at A19.

${ }^{2}$ Nontax efforts to rein in growth of the combined income/wealth gap would seem to have met with a measure of success lately. As David Leonhardt reported in The New York Times on February 17, 2015, recent analysis by George Washington University economist and research professor Steve Rose indicates that "[i]nequality has actually not risen since the financial crisis." David Leonhardt, Since the Financial Crisis, a Little Less Inequality, N.Y. TimES, Feb. 17, 2015, at A3. Federal measures to fight inequality, albeit imperfect and restrained, have apparently made a difference: a safety net of jobless

Pitt Tax Review | ISSN 1932-1821 (print) 1932-1996 (online)

DOI 10.5195/taxreview.2015.34 | http://taxreview.law.pitt.edu 
invested capital are taxed ought to be brought in line with the rates at which earned income is taxed. ${ }^{3}$ In order for the Code not to exacerbate wealth disparity, most realized returns on equity-invested capital should be subject to the same rates as generally apply to earned or "ordinary" income.

Under current law, dividends and long-term capital gains realized from corporate equity investments are generally taxed at fifteen percent. A twenty-percent rate can be incurred by high-income individuals, while a zero-percent rate on gains can conceivably inure to low-income individuals from their sales of corporate stock. Compensation, in contrast, is subjected to progressive tax rates reaching up to nearly $40 \%$. The Code fosters everincreasing wealth and income disparity through these considerable rate differences: those with accumulated capital are poised to compound its growth at a net after-tax rate enviable by wage earners whose efforts to save a portion of their net after tax compensation incomes are impeded by markedly higher ordinary income tax rates. Never before have F. Scott Fitzgerald's insightful words from "The Rich Boy" rung so true as today: "[T] he very rich ... are different from you and me." present tax treatment of long-term capital gains makes the very rich much more different! ${ }^{5}$ This tax bias involves opportunity costs, has a profoundly negative socio-economic impact, and could well foster upheaval. ${ }^{6}$

benefits, food stamps and the like cushioned the Great Recession's impact, as did the stimulus bill President Obama signed in 2009 and smaller bills passed thereafter. "Not only were low-income people protected - middle-income and some higher income-households had much lower losses because of these public policies," stated Professor Rose. Id. "For those who think government programs never work, maybe they need to think again." Id.

${ }^{3}$ A graph in The Washington Post of September 11, 2011 (based on data from I.R.S., Dep't of Treasury), tracks the relationship between federal income tax rates applicable to ordinary income and capital gains, respectively, during the preceding 65 years. Benefitting from Lower Rates, WASH. POST (Sept. 11, 2011), http://www.washingtonpost.com/business/economy/benefiting-from-lower-rates/2011/ 09/11/gIQA4ivOLK_graphic.html.

${ }^{4}$ See F. Scott Fitzgerald, The Short Stories of F. Scott FitzGerald (Matthew J. Bruccoli ed., Charles Scribner's Sons 1989) (Supposedly, based on Fitzgerald's Princeton classmate Ludlow Fowler, the full passage reads, "Let me tell you about the very rich. They are different from you and me.").

${ }^{5}$ As one would naturally expect, the economic benefit of low capital gains taxes inures predominately to individuals in the uppermost income levels. The concentration of benefits at the top is considerably greater than might be imagined, however, with fully half of the entire benefit enjoyed by those whose incomes are in the top one-tenth of one percent (over \$1,532,400 annually). Another quarter of all the benefits from low-rate capital gains taxes goes to those in the next nine-tenths of one

Pitt Tax Review | ISSN 1932-1821 (print) 1932-1996 (online)

DOI 10.5195/taxreview.2015.34 | http://taxreview.law.pitt.edu 
II.

A trio of reasons is generally offered in defense of favorable capital gains rates. Included among them is the phenomenon of "lumping": accumulated gains realized after a long-term holding period-if subjected to ordinary, progressive tax rates - would arguably be subjected to greater tax overall than if the full amount of gains realized were averaged over the asset's holding period. One problem with this rationale is that the present system fails to discriminate between assets held for one year and a day (the standard of eligibility for a favorable "long term" capital gains rate under current law) and those held for five-year, ten-year, or even longer periods. Even assuming arguendo that the "lumping" argument is valid, present law fails to address it! Moreover, the "lumping" argument conveniently

percent (whose incomes range from $\$ 126,300$ to $\$ 1,532,400$ ). And finally, $22 \%$ of the benefits from low capital gains rates are garnered by those individuals who round-out the top twenty percent highest income levels (between $\$ 126,300$ and $\$ 45,200$ ). Thus, those individuals who comprise the top $20 \%$ of annual incomes enjoy $97 \%$ of the spoils from lenient capital gain tax rates. Equally telling, a meager three percent of capital gains tax benefits trickle to $80 \%$ of our taxpayers (individuals whose annual incomes amount to $\$ 45,200$ or less). That's quite a gap. And this is not a recent phenomenon; during the last two decades, about $80 \%$ of all capital gains income realized in the United States has gone to just five percent of our population. Benefitting from Lower Rates, supra note 3.

6 "Speculative implosions," Kevin Phillips calls them, in The POLitics OF Rich AND POORWealth and the American Electorate in the Reagan Aftermath (1990). In the book, Phillip observes that the Gilded Age and Roaring Twenties were both followed by economic upheavals. Phillips raises concern over what might eventuate from the graphically demonstrable wealth-concentration trends occurring on the heels of Ronald Reagan's presidency. As Phillips documents American life in the 1980 's, the Reagan era produced immense wealth-redistributions, with the poor and working middle class losing ground, while the rich — particularly the very richest of the rich — gained in disproportionate abundance. When the Code graced corporate dividends and long-term capital gains with historically lenient rates under George W. Bush, the gulf between super-haves and the rest of us grew apace. True to form, a severe economic downturn developed late in his second term. The strong bull market during Barack Obama's presidency, ironically, served to exacerbate wealth-and-income disparities. Studies by Thomas Picketty and Emmanuel Saez disclose that during the recovery period 2009-2012, when real income growth averaged six percent, the top one percent experienced real income growth of $31.4 \%$; the bottom $99 \%$ received little of the recovery-period growth while the top one percent captured $95 \%$. While disproportionate benefits from the recovery were reaped by the very rich, wages over the long term continued to stagnate, and the power of unions (particularly those with public employee memberships) tended to erode-all contributing to the current alarm concerning wealth/income disparities. Emmanuel Saez, Striking It Richer: The Evolution of Top Incomes in the United States (updated with 2012 preliminary estimates), U.C. BERKLEY, DEP'T OF ECON. (Sept. 3, 2013), http://eml.berkeley.edu/ saez/saez-UStopincomes-2012.pdf. To be sure, severe market corrections can hurt, but if "the populist impulses of those left behind" escalate to the point of revolution, that could spell destruction. Porter, A Relentless Widening of Disparity in Wealth, supra note 1.

Pitt Tax Review | ISSN 1932-1821 (print) 1932-1996 (online)

DOI 10.5195/taxreview.2015.34 | http://taxreview.law.pitt.edu 


\section{6 | Pittsburgh Tax Review | Vol. 122015}

overlooks the value of tax deferral: capital growth goes untaxed until its owner opts to sell, or "realize" the gain; meanwhile, the investor benefits from deferral. Taxes deferred are taxes reduced, economically speaking. Consequently, the "lumping" (sometimes also called "bunching") problem tends to be overblown and, in any case, present law fails to correlate lower rates with longer holding periods. Extending a highly preferential rate to gains realized after a year-and-a-day holding period (excluding the acquisition date, but including the date of disposition), without offering any lower rate(s) as the holding period becomes truly protracted, belies "lumping" as justification for a capital gains tax rate less than half that to which earned income is exposed.

Depending upon the economic conditions prevailing over the course of an asset's holding period, it may be argued that any gains realized are not real, in an economic sense. That is to say, inflation has eroded the purchasing power of the dollar such that the proceeds from a given capital asset's sale reflect no increase. It is commonly observed that inflation taxes everyone. If it is illusory to regard capital appreciation as "gain" to the extent attributable to inflation, then what of erosion in the purchasing power of earned income? Relief for capital gains on this ground cannot be accepted as legitimate without parallel relief from the "bracket creep" that befalls workers who receive a cost of living adjustment (COLA) increase in their wages. The burden of justification that must be met by those who defend our current, widely available capital gains tax break is not met by reference to economic conditions that also affect compensation income in a similar manner.

Last and least is the contention that since most proceeds from stock sales are reinvested in the stock market, any gains realized should be granted nonrecognition. Of course, there is already in place a battery of provisions granting nonrecognition treatment to corporate mergers and multiple other types of acquisitive reorganizations, ${ }^{7}$ divisive transactions, ${ }^{8}$ stock dividends, and stock splits. ${ }^{9}$ Apart from these instances of legislative nonrecognition, the "rollover" argument suffers from two major flaws:

\footnotetext{
${ }^{7}$ I.R.C. $\S 368(\mathrm{a})(1)$.

${ }^{8} I d . \S 355$.

${ }^{9} I d$. 305 .
}

Pitt Tax Review | ISSN 1932-1821 (print) 1932-1996 (online) DOI 10.5195/taxreview.2015.34 | http://taxreview.law.pitt.edu 
stock-sale proceeds are not always or necessarily reinvested in other corporate equity interests, and even when they are, there is no assurance of the continuity generally required as a prerequisite to nonrecognition under express legislative grants - such as, for example, § 1033 (dealing with involuntary conversions). It can be argued, by analogy to the $\S 1031$ grant of nonrecognition to like-kind exchanges of realty interests, that similar treatment would be appropriate for stock sale and reinvestment situations. Inasmuch as $\S 1031$ prohibits real estate investors from being entitled to receive proceeds from a disposition, however, the analogy to most stock transactions would appear inapposite. Section 1031 itself bars nonrecognition treatment for exchanges of investments in silver for gold (and vice versa), or for differently-sexed cattle, for example-reflecting appropriate congressional refusal to allow nonrecognition treatment for transactions that fail to fit within legislatively drawn continuity lines. Continuity is the cornerstone of nonrecognition grants; in its absence, realizations trigger taxation. Apart from transactions within the above-cited nonrecognition provisions in Subchapter $\mathrm{C}$ of the Code, sales and exchanges of corporate shares have no legitimate claim for nonrecognition treatment.

In sum, each and all of the "justifications" for extending especially favorable, considerably lower tax rates to long-term capital gains, when compared with ordinary income, are unsatisfying. It would not be inappropriate to tax all capital gains the same as ordinary income (and a more simplifying, single-stroke change in the Internal Revenue Code is hard to imagine), but that is not being proposed in this essay.

Some equity investors may be heard to claim that lenient capital gain tax rates constitute a necessary incentive for them to make their investments. This mindset is somewhat akin to the gambler's quest for an "edge" to improve the odds of winning (as by counting cards when playing blackjack). When thus considered, the capital gains tax break can be seen for what it really is, and does: a means of $u n$-leveling the playing field. ${ }^{10}$ Unfairness becomes apparent once the fallacies inherent in the "justifications" for capital gain tax leniency are exposed. Basically, the

${ }^{10}$ That our capital gains tax break departs from the vaunted "free market" cannot be gainsaid.

Pitt Tax Review | ISSN 1932-1821 (print) 1932-1996 (online) DOI 10.5195/taxreview.2015.34 | http://taxreview.law.pitt.edu 
capital gains tax break is like carrying coals to Newcastle by favoring already inherently favored investments. ${ }^{11}$

III.

When Ronald Reagan became President, there was a "maximum tax" of $50 \%$ on earned income. At the same time, progressive rates ran up to a high of 70\%. One of President Reagan's first tax moves was to reduce that top rate to $50 \%$. The beneficiaries of such rate reduction were clearly those with high levels of unearned income. Now that currently profound disparities in wealth and income levels have begun attracting attention (to the point of provoking grave concern ${ }^{12}$ in some circles $^{13}$ ), today's tax

\footnotetext{
${ }^{11}$ In his 1924 book, Common Stocks as Long Term Investments, Edgar Lawrence Smith showed that there is inherently a relative advantage in equity investing for realizing greater returns. Further to this, see Roger G. Ibbotson \& Rex A. Sinquefield, Stocks, Bonds, Bills, and Inflation: Year-by-Year Historical Returns (1926-1974), 49 J. Bus. 11 (1976) and Roger G. Ibbotson \& Rex A. Sinquefield, Stocks, Bonds, Bills, and Inflation: Simulations of the Future (1976-2000), 49 J. BuS. 313 (1976).

${ }_{12}$ See, e.g., Nick Hanauer, The Pitchforks Are Coming ... For Us Plutocrats, Politico MAGAZINE (July/Aug. 2014), available at http://www.politico.com/magazine/story/2014/06/thepitchforks-are-coming-for-us-plutocrats-108014.html\#.VRC23zTF-c8 ("I see pitchforks. At the same time that people like you and me are thriving beyond the dreams of any plutocrats in history, the rest of the country - the 99.99 percent - is lagging far behind. The divide between the haves and have-nots is getting worse really, really fast. In 1980, the top 1 percent controlled about 8 percent of U.S. national income. The bottom 50 percent shared about 18 percent. Today the top 1 percent share about 20 percent; the bottom 50 percent, just 12 percent. But the problem isn't that we have inequality. Some inequality is intrinsic to any high-functioning capitalist economy. The problem is that inequality is at historically high levels and getting worse every day. Our country is rapidly becoming less a capitalist society and more a feudal society. Unless our policies change dramatically, the middle class will disappear, and we will be back to late 18th-century France. Before the revolution. And so I have a message for my fellow filthy rich, for all of us who live in our gated bubble worlds: Wake up, people. It won't last. If we don't do something to fix the glaring inequities in this economy, the pitchforks are going to come for us. No society can sustain this kind of rising inequality. In fact, there is no example in human history where wealth accumulated like this and the pitchforks didn't eventually come out. You show me a highly unequal society, and I will show you a police state. Or an uprising. There are no counterexamples. None. It's not if, it's when.... Revolutions, like bankruptcies, come gradually, and then suddenly. That's the way it always happens. If inequality keeps rising as it has been, eventually it will happen. We will not be able to predict when, and it will be terrible-for everybody. But especially for us."). The nightmare Mr. Hanauer envisions should not be confused with repentance for his riches. Most of the very rich feel entitled to what they have, and many object vociferously to any government action that might threaten it. See, for example, James Surowiecki, Moaning Moguls, NEW YORKER (July 7, 2014), http://www .newyorker.com/magazine/2014/07/07/moaning-moguls, where Surowiecki reports on the attitudes of venture capitalist Tom Perkins, Home Depot co-founder Kenneth Langone, and Blackstone Group chairman/CEO Stephen Schwarzman. The mind-set of Warren Buffett (Berkshire-Hathaway), questioning why his secretary pays a higher rate of tax than he does, is atypical.
}

Pitt Tax Review | ISSN 1932-1821 (print) 1932-1996 (online)

DOI 10.5195/taxreview.2015.34 | http://taxreview.law.pitt.edu 
policies need to be influenced by a heightened respect for earned income, coupled with a reduced reverence toward capital gains.

Along the way, any fear mongering rhetoric about "taxing capital" ought to be disregarded. Capital cannot be taxed as income. However broadly "income" might be defined, it can never encompass recoveries of capital; the "incomes" reference in the Sixteenth Amendment (authorizing the federal income tax) must be accorded its ordinary meaning, and capital recoveries have never been thought of as income. Unlike capital recoveries, however, returns on capital are allowed to be income-taxed. The problem is that, today, some returns on capital are taxed all too weakly. Revenue Code amendments are needed to target money begat by money - such as dividends and realized gains - far more effectively than the fifteen percent rate they generally enjoy under current law. Otherwise, the mounting threat posed by income and wealth disparities will persist. Left unchecked, those disparities threaten to grow exponentially.

Narrowing the type of investments eligible to qualify for the fifteen percent tax rate could yield widespread wealth-generating effects. Most corporate equity investments that produce leniently taxed gains today are in

${ }^{13}$ See Rick Newman, The Rich Can Stop Worrying About a Middle-Class Revolution, YAHOO! (June 27, 2014, 11:18 AM), http://finance.yahoo.com/blogs/daily-ticker/why-the-rich-are--mistakenly-worried-about-the-middle-class-151842954.html ("[I]n functioning democracies (and even in the United States), there's plenty of warning when social unrest is percolating. These days ... you'll encounter plenty of angst - but not much revolutionary zeal. The economic trends Hanauer identifies are, in fact, real problems. America as a whole will suffer if the fortunes of the middle class don't improve. There are solutions, however, and they'll probably materialize in the usual American way-right before disaster strikes. It's nearly inevitable there will be government spending cuts and, yes, tax hikes.").

Newman is probably correct, but here's the rub: Federal government spending cuts tend adversely to affect lower economic classes more considerably than they crimp lifestyles of wealthy individuals; and as for tax hikes, there is precious little sign of our reverting to a truly progressive income tax rate structure. Progressivity would first require proliferating the number of rate brackets. Ronald Reagan succeeded in selling the notion that tax-law simplification results from fewer rate-brackets, but in reality the tax tables obviate any complexity from multiple rate brackets. Speculating further on what "tax hikes" might eventuate in the face of a pending disaster: Federal gratuitous transfer tax exemptions might get reduced to $\$ 3$ million (with "portability" retained) and the top rate increased; $§ 1014$ grant of fair-market-value basis to property held by decedents at death is repealed (again); the ceiling amount above which wages are not subjected to FICA (social security) taxes is either raised or eliminated; the $\S 162(\mathrm{~m})$ disallowance of publicly-held-corporation deductions for compensation paid in excess of $\$ 1$ million to any of the five highest-paid workers is tightened; and scope of the capital gains tax benefit is curtailed. It would remain to be seen whether any or all such changes, based on "ability to pay" and the "marginal utility of money," sufficed to placate the bottom $90 \%$.

Pitt Tax Review | ISSN 1932-1821 (print) 1932-1996 (online) DOI 10.5195/taxreview.2015.34 | http://taxreview.law.pitt.edu 
what might be referred to as "used" stocks. Millions of such shares are traded daily on the New York Stock Exchange (NYSE), Alternext US (former Amex or Curb Exchange), National Association of Securities Dealers Automated Quotations (NASDAQ), Over-The-Counter (OTC), and other markets. Most significantly, no direct enrichment inures to the issuing corporations from the vast bulk of those millions of trades occurring every day. It is also important to note that no special tax lure attracts those who might consider investing in a relatively new venture that is either just being incorporated, or on the verge of going public. By discontinuing favored capital gain tax rates for "used" stock investment profits, new issues will naturally emerge as a uniquely tax-incentivized investment opportunity. It makes good sense for federal income tax law to reward the creative, the entrepreneurs, and risk-takers: it is their businesses that are most apt to become new "job creators."

Today we reward investors willy-nilly, by offering enviably low fifteen percent capital gains tax rates across the board, without any differentiation being drawn between those investing in new businesses and those trading in "used" stocks. Let's face it: the latter activities do little more than grow brokerage service business profits. The markets will continue to function unabated in absence of a lenient tax rate on gains realized from stock dispositions. For that matter, conditions more closely resembling the vaunted "free market" will be at hand once capital gains tax leniency is withdrawn from "used" stock transactions. More to the point, nascent businesses and expanding corporate entities can be expected to attract capital with greater facility than in the present "willy-nilly" worldonce capital gains tax breaks are reserved for them alone.

$$
\text { IV. }
$$

When it comes to losses, the Code already differentiates in favor of select original-issue share investors. Section 1244 allows long-term losses realized by original-issue shareholders of $\S 1244$ stock to be taken as ordinary loss deductions. This tax treatment is beneficial because ordinary losses can be utilized to offset ordinary income without limitation. The taxsaving value of an ordinary loss deduction can approach 40 cents on the dollar, rather than only fifteen or twenty cents (from a long-term capital loss deduction), with the additional likely benefit of there being no material delay before the deduction can be claimed. Apart from the favorable ordinary loss characterization afforded to original-issue stockholders of small business corporations under $\S 1244$, capital losses must generally be

Pitt Tax Review | ISSN 1932-1821 (print) 1932-1996 (online)

DOI 10.5195/taxreview.2015.34 | http://taxreview.law.pitt.edu 
taken as a deduction against capital gains. ${ }^{14}$ It is here being proposed that the special tax break currently provided for taxpayer losses from $\S 1244$ stock be mirrored on the profit side - with a favorable rate exclusively available only to original-issue shareholders' gains.

When individual investors' capital losses on "used" shares exceed capital gains realized for the year, $\S 1211$ (b) allows them to deduct the excess against ordinary income to the extent of $\$ 3,000$ per year. Beyond that amount, the capital loss must be carried over to the next year, further reducing its tax-saving value by dint of deferral. Essentially, the $\S 1211(\mathrm{~b})$ allowance grants the first $\$ 3,000$ of an individual investor's excess losses on "used" shares the same ordinary-loss-characterization benefit as $\S 1244$ affords to original-issue, small business corporation shareholder losses. The presumably unintended effect of $\S 1211(\mathrm{~b})$ is to undercut the laudable $\S 1244$ incentive that favors investment in original issue shares of new ventures. Were gains realized from the sale or exchange of "used" shares taxed at the same rate(s) as ordinary income, so too would losses realized from dispositions of such stock be treated as ordinary. Section 1211(b) would then become detritus. While this would only slightly simplify the Code and its administration, every little bit helps.

Offering the best of both worlds to $\S 1244$ stockholders-by way of either a lenient-taxed capital gain if the entity thrives, or an ordinary loss deduction if it does not — can be seen as a reasonable means of incentivizing original-issue capital investment in small business entities. To the extent $\S 1211$ (b) waters down the incentive by providing all individual shareholders the same benefit for their first $\$ 3,000$ of excess capital loss, it can be rationalized on tolerable grounds of administrative simplification. For real improvement, though, the lenient fifteen percent long-term gains rate ought to be made limitedly available to the same type of original-issue shareholders as currently benefit from $\S 1244$ on the loss side-and with that, no reason for $\S 1211$ (b) would exist any longer.

${ }^{14}$ See I.R.C. $§ 165(\mathrm{~g})(1)$.

Pitt Tax Review | ISSN 1932-1821 (print) 1932-1996 (online) DOI 10.5195/taxreview.2015.34 | http://taxreview.law.pitt.edu 
V.

One devilish detail deserving attention arises when an original offering is over-subscribed. We could brush those not uncommon situations aside, as apparently needing no incentive to attract venture capital. But the fortunate original issuees could still benefit from a fifteen-percent rate on gain realized from the sale of their shares, while those who were denied an allocation of original-issue shares would not. So be it. One anticipated after-effect of this might be an increased focus on how share allocations of over-subscribed original issues are made, in the interest of achieving greater fairness. Care must also be taken in defining the parameters of "original issue." Some public offering connotation is probably preferable, but what of divisive distributions (spin-off, split-off, or split-up) that yield the first public ownership of a given entity? And what of stock dividends reflected by corporate-level additions to capital accounts (in amounts equal either to the distributed shares' par or stated values)? Are such shareholders "original" issuees? As for the "small business corporation" concept, which presently limits availability of $\S 1244$ benefits to entities with no greater than $\$ 1$ million capitalization, ${ }^{15}$ that ceiling should be raised significantly in order to comport with capitalization levels being witnessed in most of today's new ventures.

Something of a pet peeve, even among many members of the investment community, is the capital asset treatment accorded a "carried interest," which is inherently a corporate equity interest received as compensation. While articulating metes and bounds of the "capital asset" concept can from time to time prove challenging, this is not one of those instances. The Supreme Court's approach in Bingler v. Johnson ${ }^{16}$ would be appropriate for dealing with "carried interest" type situations as compensation income. Further guidance can be taken from $\S 83$ to indicate the appropriate "ordinary income" characterization of gains attributable to personal expertise and effort. Despite the fact that original-issue shares may

\footnotetext{
${ }^{15}$ See id. $\S 1244(\mathrm{c})(1)(\mathrm{A}),(\mathrm{c})(3)(\mathrm{A})$.
}

16394 U.S. 741, 757 (1969). Although involving surface facts indicative of scholarship or fellowship benefits - that generally would be rendered tax exempt by $\S 119$ - the Court in Bingler declined to exempt them from tax. Because the taxpayer-recipients were past and future employees of Westinghouse, which was also the corporate sponsor of the educational benefits, their costs were properly declared taxable as compensation.

Pitt Tax Review | ISSN 1932-1821 (print) 1932-1996 (online) DOI 10.5195/taxreview.2015.34 | http://taxreview.law.pitt.edu 
well be involved in the "carried interest" context, they should be considered undeserving of characterization as capital assets. ${ }^{17}$

VI.

Finally, corporate stock is hardly the only capital asset: $\S 1221$ defines "capital asset" rather expansively as "property." Corporate stock is certainly the most heavily traded of all capital assets, though, and maintains its capital asset status despite the volume and frequency of an investor's trading activity. It can therefore legitimately be considered the paradigm capital asset. ${ }^{18}$ Considering the magnitude of gains (and losses) realized daily from sales of corporate stock, it makes sense to target them for betterthought-through tax treatment than under current law. The reasons offered to explain or rationalize today's preferential long-term capital gains tax rates do not stand up to critical scrutiny, and their widespread availability squanders what could instead serve as a well-targeted incentive for fostering investment in nascent public-held businesses that tend to hire new employees.

Because of its high-volume market prominence, some might regard corporate stock gains taxation as an ill-chosen target for reform, if only out of concern that major market disruptions might result. Experience for a period of years during the Reagan presidency, beginning with the 1986 Act when capital gains were taxable at the same $28 \%$ top-rate level as earned or "ordinary" income, should allay fears that a financial market upheaval lies in store with adoption of the reform here proposed.

${ }^{17}$ See Darryll K. Jones, Testimony Concerning the Tax Treatment of Compensation Paid to Hedge, Private Equity and Venture Capital Fund Managers before the Committee on Finance, United States Senate (2007), available at http://www.finance.senate.gov/imo/media/doc/073107testdj.pdf.

${ }^{18}$ Two other capital asset categories sufficiently prominent to have warranted idiosyncratic longterm rates are real estate and collectables. Property in the latter category benefits from a $28 \%$ rate on realized long-term gains. While realized real estate gains can actually enjoy the fifteen percent tax rate, depreciated (structural) realty draws a mild, ersatz form of recapture via $25 \%$ rate - and investors with frequent realty sales can lapse into dealer status and thereby lose capital asset treatment altogether. (Beyond the rates at which gain from realty sales may be taxed, a panoply of Revenue Code provisions pertains to real estate, extending well beyond the scope of this essay.)

Pitt Tax Review | ISSN 1932-1821 (print) 1932-1996 (online) DOI 10.5195/taxreview.2015.34 | http://taxreview.law.pitt.edu 
VII.

The title of this essay, "My Last Time," relates to my appearance as witness before the U.S. House Ways and Means Committee, when I was put on a panel that included a high-ranking corporate officer. Not surprisingly, my fellow panel members tended to favor tax beneficence toward capital gains. After each of us had presented our respective prepared remarks, questions were addressed to us by Representatives on the Committee. It was then that the proposal being forwarded here came to mind. I posed my idea in the form of a hastily written question, which I passed to the corporate officer who was seated to my left: would he endorse limiting lenient capital gains tax treatment to original-issue shareholders? "Yes." This was prior to our Reagan-era experience with rate parity between capital gains and ordinary income. It was also long before wealth and income disparities reached the orders of magnitude observable today. It is high time for the Code to stop exacerbating economic conditions that are deleterious to democracy. The present proposal qualifies as a reasonable, highly recommended step in that direction.

By way of full disclosure, my preoccupation with capital gains taxation hardly began with the aforesaid appearance before House Ways and Means. During academic year 1962-1963, I had the benefit of Geoffrey Lanning as my teacher in a year-long federal income taxation course at The Catholic University of America's Columbus School of Law. Professor Lanning occasionally asked our class, "Why capital gains?" Whether he intended the inquiry to be rhetorical or not I will never know, but I have yet to find a satisfactory answer. Professor Marvin Chirelstein, who I had the pleasure of knowing while a graduate student at Yale Law School, comes closest in his Federal Income Taxation text. He suggests that the "double imposition" on savings (the first being incurred during the course of accumulating after-tax capital for investment, and the second being incurred on earnings collected from that capital) might serve to explain the capital gain tax bias as a form of attempted mitigation. ${ }^{19}$ While this is plausible as a psychological motivation, it is no legal justification for long-term capital gain tax breaks!

${ }^{19}$ MARvin A. Chirelstein, Federal Income TAXAtion 364 (11 th ed. 2009).

Pitt Tax Review | ISSN 1932-1821 (print) 1932-1996 (online) DOI 10.5195/taxreview.2015.34 | http://taxreview.law.pitt.edu 
My dissatisfaction with the Code in this regard was first aired in "The myth of capital gains taxes," published in The New York Times Business and Finance Section (Sunday, August 14, 1977), which provoked an "unprecedented flow" of letters to the editor. More recently, near year's end about 30 months ago, as a ritualistic logjam (though one could well ask, "where are the logs?") was playing out in Washington, D.C., I tried a different tack by proposing to "tax all income equally." "The myth" of yore seemed by then to have produced an invasive species of wealth concentration that might be controlled by taxing all incomes the same, but the present political environment effectively prohibits serious consideration of that solution. As the uncollected tax revenues attributable to gains realized from dispositions of "used" stock (scattered over several lines in the tax expenditure budget) mount, and our nation's socio-economic stratification worsens, something must soon be done in order to stem the rising tide - one that is manifestly not lifting all boats.

Finally, it would be erroneous to infer that this essay represents my "evolved" stance on capital gains taxation. Endorsement of the modest, logical and politically plausible ${ }^{21}$ stopgap measure forwarded here is called for simply because of where we are and where we are headed. ${ }^{22}$ Narrowing availability of capital gain tax benefits to original-issuees hardly promises to reduce the income/wealth gap; it merely lessens Code complicity in

${ }^{20}$ See William J. Brown, Tax All Income Equally; This Is a Good Time to Make Our Tax Code Simpler and Fairer, PITTSBURGH PoST-GAZETTE, Dec. 28, 2012, at B-7 ("It's a steep uphill climb for an income-earning worker to maintain pace with an investor of capital, even if their respective taxable incomes start at identical amounts. After both pay federal income tax, the capital investor will likely have more net income and consequently pull away from the more heavily tax-burdened worker. Present tax law thereby fosters an ever-increasing gap, year after year, between the two of them.").

${ }^{21}$ But see Martin Gilens \& Benjamin I. Page, Testing Theories of American Politics: Elites, Interest Groups, and Average Citizens, 12 PERSP. ON POL. 564, 573 (2014) ("The [U.S. government] system has a substantial status quo bias. Thus when popular majorities favor the status quo, opposing a given policy change, they are likely to get their way; but when a majority - even a very large majorityof the public favors change, it is not likely to get what it wants. In our 1,779 policy cases, narrow prochange majorities of the public got the policy changes they wanted only about 30 percent of the time. More strikingly, even overwhelmingly large pro-change majorities, with 80 percent of the public favoring a policy change, got that change only about 43 percent of the time.").

${ }^{22}$ Id. at 576 ("Our findings also point toward the need to learn more about exactly which economic elites (the merely affluent? the top one percent? the top one-tenth of one percent?) have how much impact upon public policy, and to what ends they wield their influence.").

Pitt Tax Review | ISSN 1932-1821 (print) 1932-1996 (online) DOI 10.5195/taxreview.2015.34 | http://taxreview.law.pitt.edu 


\section{6 | Pittsburgh Tax Review | Vol. 122015}

worsening the problem. As I have said, it is modest—all the more reason for adopting it.

Respectfully,

William J. Brown

Pitt Tax Review | ISSN 1932-1821 (print) 1932-1996 (online)

DOI 10.5195/taxreview.2015.34 | http://taxreview.law.pitt.edu 